\title{
FENOMENA GUGAT CERAI ALASAN IMPOTENSI (Studi di Pengadilan Agama Kota Malang)
}

\author{
Imam Nuril Shofiyuddin \\ Staf Pusat Studi Gender (PSG) UIN Malang \\ dan Mahasiswa Magister Ilmu Hukum PPS Unisma
}

\begin{abstract}
ABSTRAK
Kompleksitas fenomena yang terjadi di masyarakat sangatlah beragam, diantaranya adalah fenomena yang terjadi dalam kelompok terkecil dalam masyarakat ; keluarga. Dalam sebuah keluarga fenomena gugat cerai merupakan masalah yang sering dijumpai, yakni seorang istri yang mengajukan gugatan perceraian kepada Pengadilan Agama karena alasan impotensi. Impotensi diartikan ketidakberdayaan pria melakukan hubungan seks melalui alat kelaminnya. Masalah impotensi dalam beracara di Pengadilan Agama dapat dijadikan salah satu pertimbangan hakim dalam memutuskan perkara perceraian, hal ini karena sudah sesuai dengan pasal 116 huruf (e) Kompilasi Hukum Islam (KHI).
\end{abstract}

\section{A. PENDAHULUAN}

Perkawinan sebagaimana yang disebutkan dalam pasal 2 Kompilasi Hukum Islam (KHI) adalah pernikahan, yaitu akad yang sangat kuat atau mitsaqan ghalidlan untuk mentaati perintah Allah dan melaksanakannya merupakan ibadah. ${ }^{1}$ Perkawinan pada dasarnya lebih merupakan kontrak sosial antara seorang pria dan wanita untuk hidup bersama yang dilandasi dengan niat ibadah untuk membangun dan membina rumah tangga.

Terminologi mitsaqan ghalidlan yang berarti perjanjian yang kokoh dapat dipahami dalam al-Qur'an surat al-Ahzab ayat 7 :

"dan (ingatlah) ketika kami mengambil perjanjian dari nabi-nabi dan dari kamu (sendiri), dari Nuh, Ibrahim, Musa dan Isa putera Maryam, dan kami telah mengambil mereka perjanjian yang kokoh.

Perjanjian yang kokoh sebagaimana juga dimaksud dalam pasal 2 UU No. 1 tahun 1974, yakni, perkawinan ialah ikatan lahir batin antara seorang pria dengan seorang wanita sebagai suami istri dengan tujuan membentuk

\footnotetext{
${ }^{1}$ Cik Hasan Bisri, Kompilasi Hukum Islam dan Peradilan Agama, (Jakarta : Logas Wacana Ilmu, 1999) hal. 140.
} 
keluarga (rumah tangga) yang bahagia dan kekal berdasarkan ketuhanan Yang Maha Esa.

Meskipun tujuan perkawinan adalah untuk selama-lamanya, akan tetapi Islam memperbolehkan perceraian dengan alsan yng bisa dipertanggungjawabkan secara hukum. Dalam artian perceraian merupakan alternative terakhir yang boleh ditempuh apabila kehidupan rumah tangga tidak dapat dipertahankan, yang sebelumnya harus ditempuh usaha-usaha perdamaian antara kedua belah pihak, baik melalui hakim atau melalui langkah-langkah solutif lainnya.

Perceraian dapat terjadi karena alasan-alasan tertentu, diantaranya adalah karena salah satu pihak mendapat cacat badan atau penyakit dengan akibat tidak dapat menjalankan kewajibannya sebagai suami istri, sebagaimana yang tercantum dalam pasal 116 KHI huruf (e). Pengertian penyakit yang mengakibatkan suami tidak dapat menjalankan kewajibannya adalah impotensi.

\section{B. Definisi Impotensi}

Tidak ada satu definisi yang tepat untuk mengartikan kata impotensi. Banyak yang mengatakan bahwa impotensi adalah ketidakmampuan untuk ereksi yang cukup kuat untuk melakukan hubungan seks. Sementara yang lain mengatakan bahwa impotensi adalah ketidakmampuan penis untuk mempertahankan ereksi yang kuat. ${ }^{2}$

Impotensi berasal dari kata impotent, yang terdiri dari im yang berarti tidak dan potent yang berarti mampu Jadi secara harfiah impoten artinya ketidakmampuan. Dalam bidang kedokteran, impoten selalu dihubungkan dengan masalah seksual, sehingga impoten diartikan sebagai ketidak mampuan pria untuk melakukan hubungan seks. Secara spesifik, impotensi adalah ketidak berdayaan pria melakukan hubungan seks melalui alat kelaminnya. ${ }^{3}$

\footnotetext{
${ }^{2}$ Marg, Ragg Mengatasi Impotensi (Jakarta : Arcan, 2002) hal. 1

${ }^{3}$ Hembing, Wijayakusuma, Mengatasi Impotensi Secara Efektif dan Alamiah, (Jakarta : PT Elex Media Komputindo, 2000) Hal. 5
} 
Banyak istilah dan terminologi untuk impotensi, seperti lemah syahwat, gangguan ereksi, disfungsi ereksi, mati pucuk batang zakar, dan lainlain. Istilah-istilah ini pada hakikatnya memberikan gambaran tentang ketidakmampuan seorang pria dalam melakukan hubungan seks karena tidak berhasil membangkitkan dan mempertahankan ereksinya (ketegangan alat kelamin) dengan baik dan melakukan penetrasi ke dalam vagina.

Hingga kini masih banyak anggapan yang simpang siur dan keliru mengenai masalah impotensi. Banyak yang menganggap bahwa umur sangat berpengaruh terhadap kemampuan seksual. Orang menduga bahwa pria akan menjadi impoten setelah berusia sekitar 50 tahun ke atas, namun pada kenyataannya diantara pria-pria tersebut masih banyak mampu melakukan hubungan seks dan menghasilkan keturunan.

Sebagian orang mengatakan bahwa impotensi adalah suatu penyakit di mana penderitanya tidak dapat melakukan seks dan tidak dapat mencapai orgasme sebagian atau menyeluruh. Sebagian orang lagi mengatakan bahwa impotensi itu adalah semua gangguan dalam bidang seksual, termasuk ejakulasi dini, berkurangnya gairah seksual, homoseksual, dan lain-lain yang berkaitan erat dengan seksualitas pria.

Ereksi akan terjadi jika pria merasakan adanya rangsangan pada alat kelaminnya. Ereksi pada pria sulit dijabarkan secara jelas, tetapi sebagian besar pria mengetahui secara pasti kapan ereksi penuh, ereksi sebagian, ereksi kurang sempurna, atau tidak ereksi sama sekali. Dalam keadaan tidak ereksi, hubungan seks akan sangat sulit dilakukan.

Dari uraian di atas dapat dijelaskan bahwa impotensi adalah ketidak mampuan pria mencapai ereksi secara sempurna, sehingga gagal berpenetrasi pada vagina dan koitus mengalami kegagalan. Perlu diingat bahwa pria yang mandul tidak berarti impoten, karena masalah mandul terletak pada spermanya, sementara organ seksualitas masih berfungsi dengan baik dan dapat melakukan koitus dengan sempurna. 


\section{Faktor Penyebab Impotensi}

Impotensi termasuk penyakit seksual pria yang sangat menyiksa kaum pria. Banyak kaum pria yang putus asa karena penyakit ini. Secara garis besar impotensi disebabkan oleh faktor fisik dan faktor psikis.

\section{a. Faktor Fisik}

Faktor fisik lebih berpengaruh sebagai pemicu timbulnya impotensi, Secara garis besar Prof. H. M. Hembing Wijayakusuma merumuskan pada fisik pria terdapat delapan faktor penyebab impotensi. ${ }^{4}$ Seperti akibat gangguan kesehatan, kebiasaan merokok, kurang berolahraga, faktor genetika, adanya kelainan pada saraf dan anggota tubuh, pengkonsumsian obat-obatan, kastraksi (pembuangan kelenjar kelamin), dan pengaruh radioterapi.

\section{b. Faktor Psikis}

Banyak hal yang secara psikis dapat menimbulnya impotensi, Prof. H. M. Hembing wijayakusuma secara garis besar merumuskan lima macam faktor psikis penyebab impotensi, yaitu $: 1$. Perasaan Takut, 2. Kegagalan Mencapai Kepuasan Koitus Pertama 3. Tegang, Gelisah, Stres dan Depresi, 4. Perceraian, 5. Cinta dan Perselingkuhan. Perselingkuhan yang dilakukan suami dapat mengakibatkan hasrat seksual pada pasangan sahnya akan menurun atau bahkan tidak berhasrat lagi.

Suami yang sudah pernah berselingkuh dan melakukan senggama akan dikuasai rasa takut ketahuan, takut tertular atau menularkan penyakit kelamin, jijik, perasaan benci, atau perasaanperasaan lainnya yang dapat membuat suami menderita impotensi.

\section{Kadar Impotensi}

Kadar impotensi pada umumnya terbagi menjadi dua. Pertama, kadar impotensi yang permanen, ini sulit atau bahkan tidak bisa sembuh seratus persen. Kadar seperti ini kebanyakan disebabkan oleh faktor fisik dan sekaligus psikis. Kedua, kadar impotensi yang sementara dan dapat

\footnotetext{
${ }^{4}$ Hembing, Wijayakusuma, ibid. Hal. 25
} 
disembuhkan. Hal ini disebabkan oleh faktor psikis, jika perasaan psikis ini dapat dihilangkan. Penyakit impotensi cenderung bisa sembuh secara total.

\section{Dampak Impotensi}

Dikarenakan kadar impotensi yang berbeda, maka dampaknya pun juga variatif. Untuk lebih spesifik, dampak impotensi yang penulis maksud adalah terhadap pernikahan. Dengan kata lain, dampak dari penyakit impotensi yang permanen terhadap pernikahan terbagi menjadi dua, yakni dampak secara fisik dan psikis.

a. Dampak Fisik

Secara fisik dampak impotensi permanen, terhadap pernikahan mengakibatkan fakumnya sentuhan seksual antara suami dan isteri. Jika hal ini terus berlanjut maka suatu pernikahan rumah tangga akan menjadi tidak harmonis dan berlanjut pada perceraian.

b. Dampak Psikis

Adapun dampak secara psikis, impotensi terhadap hubungan pernikahan mengakibatkan suami tidak percaya diri, gelisah, malu dan putus asa karena merasa tidak mampu melaksanakan kewajibannya sebagai suami, yakni memberi nafkah batin baik berupa sentuhan seksual maupun keturunan. Dari pihak isteri merasa gelisah dan resah karena tidak bisa menerima haknya dari suami.

Ayidah Ahmad Shalal berpendapat bahwa pernikahan yang berhasil dan harmonis, berlandaskan pada beberapa unsur tertentu. Unsurunsur yang bisa dianggap sebagai faktor-faktor kehidupan pernikahan yang sukses, yaitu :

1) Kehadiran

2) Komunikasi

3) Sentuhan

4) Simpati

5) Komitmen

6) Kompeten 
Jika suatu pernikahan tidak disertai dengan adanya sentuhan, maka akan berdampak pada ketidakharmonisan rumah tangga serta ketidakberhasilan dalam menjalani misi dan visi pernikahan. Tidak jarang terdapat pernikahan yang gagal dikarenakan suami mengalami impotensi, bahkan ada yang sampai berujung pada perceraian.

Dengan maksud lain, dampak impotensi terhadap perkawinan adalah pilihan antara dua putusan dari pihak isteri. Dua pilihan tersebut yaitu ; (1) isteri menerima keadaan suaminya yang impoten sebagai kepala rumah tangga dan tetap melanjutkan perkawinannya, atau (2) isteri memilih melakukan gugat cerai dengan alasan suami mengalami cacat badan yang berupa impotensi dengan akibat tidak dapat menjalankan kewajiban sebagai suami.

Putusan antara dua pilihan tersebut sepenuhnya adalah hak isteri karena suami tidak mampu menjalankan kewajibannya disebabkan impotensi. Isteri merupakan obyek utama dari dampak impotensi terhadap perkawinan. Maka isteri pun berhak mengambil sikap dalam perkawinan tersebut.

\section{Gugat Cerai}

Pada dasarnya melakukan perkawinan itu adalah bertujuan untuk selama-lamanya, tetapi adakalanya sebab-sebab tertentu yang mengakibatkan perkawinan tidak dapat diteruskan dan harus diputuskan di tengah jalan atau terpaksa putus dengan sendirinya, atau dengan kata lain terjadi perceraian antara suami-isteri. Salah satu bentuk perceraian adalah gugat cerai, dalam kajian teori ini akan dibahas mengenai gugat cerai dan impotensi yang nantinya dijadikan alat untuk menganalisis pada bab selanjutnya.

\section{Gugat Cerai Menurut Hukum Islam}

Perceraian diperbolehkan dalam Islam karena pernikahan dianggap sebagai sebuah kontrak, yang dapat diputuskan baik karena kehendak keduanya atau karena kehendak salah satu pihaknya. Bertentangan dengan kepercayaan umum, Islam juga memperbolehkan perempuan mempunyai hak cerai. Perceraian itu dapat dilakukan dengan jalan tebus (khuluk), 
yaitu isteri minta ditalak (dicerai) suaminya dengan memberikan kepada suami harta yang pernah diterimanya sebagai maskawin ${ }^{5}$.

Adanya kemungkinan bercerai dengan jalan khuluk ini ialah untuk mengimbangi hak talak yang ada pada suami. Dengan khuluk ini si isteri dapat mengambil inisiatif untuk memutuskan hubungan perkawinan dengan cara penebusan.

\section{a. Pengertian Khuluk}

Khuluk menurut bahasa artinya menanggalkan atau melepaskan, seperti melepaskan pakaian (khol'its tsaub). Kemudian makna ini dipakai dengan arti "melepaskan isteri”, karena al-Qur'an mengumpamakan isteri itu sebagai pakaian dari suami dan suami adalah pakaian dari isteri. ${ }^{6}$ Sebagaimana firman Allah swt dalam surat Al-Baqarah ayat 187 :

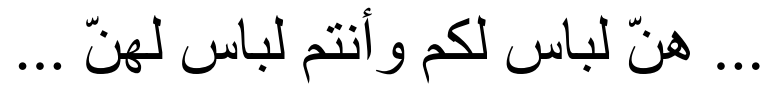

Artinya : ... "Mereka itu adalah pakaian bagimu dan kamu pun adalah pakaian bagi mereka" ...

Menurut Rusyd, Khuluk adalah pemberian oleh isteri kepada suami semua harta yang diberikan suami kepadanya. ${ }^{8}$

Khuluk menurut istilah ilmu Fiqh berarti : menghilangkan atau mengurungkan akad nikah dengan kesediaan isteri membayar 'iwadh (ganti rugi) kepada pemilik akad nikah itu (suami) dengan menggunakan perkataan cerai atau khuluk. 'Iwadh dapat berupa mahar oleh isteri kepada suami atau sejumlah barang, uang atau suatu yang dipandang mempunyai nilai yang telah disepakati oleh kedua suami dan isteri. ${ }^{9}$

\footnotetext{
${ }^{5}$ Ahmad Basyir Azhar, Hukum Perkawinan Islam, (Yogyakarta : UII Press, 2004) hal. 81

${ }^{6}$ Alhamdani, A, S,. Risalah Nikah, (Jakarta : Pustaka Amani, 2002) hal. 261

${ }^{7}$ Al-Qur'an dan Terjemahnya, Jakarta, Departemen Agama RI, 2000. hal. 45

${ }^{8}$ Ibnu, Rusyd, Terj. Abdurrahman dan Abdullah, Haris, Bidayatul Mujtahid, (Semarang : CV. Asyifa. 1990). Hal. 489.

${ }^{9}$ Ibnu, Rusyd, ibid. Hal. 489.
} 
Para Ulama Mazhab sepakat bahwa harta tebusan dalam khuluk hendaknya mempunyai nilai, dan bahwa jumlahnya boleh sama, kurang atau lebih banyak daripada mahar. ${ }^{10}$

\section{b. Alasan-Alasan Khuluk}

Para Imam Mazhab empat sepakat bahwa isteri tidak senang kepada suaminya lantaran keburukan muka atau buruk pergaulan yang ada pada suami dapat dijadikan alasan khuluk. Dan jika suami-isteri setuju untuk melakukan khuluk tanpa sebab apapun maka hal itu sah akan tetapi makruh. Pendapat ini bertentangan dengan az-Zuhri, 'Atha' dan Dawud yang berpendapat ; khuluk tanpa sebab apapun adalah tidak sah.

Muhammad Jawad Mughniyah dalam kitab fikih lima mazhab menyatakan bahwa khuluk hanya dibolehkan kalau ada alasan yang benar, seperti suami cacat badan, jelek akhlaknya atau tidak memenuhi kewajiban terhadap isterinya, sedangkan isteri khawatir akan melanggar hukum Allah. Jika tidak ada alasan yang benar hukumnya terlarang. Sebagiamana keterangan hadits Ahmad dan Nasa'i dari Abu Hurairah :

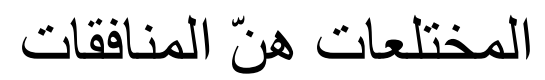

Artinya : Isteri-isteri yang minta khulu' adalah perempuan munafik.

Para Ulama berpendapat bawha khuluk tanpa alasan hukumnya makruh. ${ }^{11}$

Pendapat sebagian besar Ulam khuluk boleh dan sah dilakukan dengan alasan sebagai berikut :

1) Suami hilang atau dipenjara

${ }^{10}$ Sabiq, Sayyid. Fikih Sunnah 8, (Bandung : PT. Almaarif 1993) hal. 457

11 Mughniyah, Jawad, Muhammad, Fiqih Lima Mazhab, (Jakarta : PT. Lentera Basritama. 2001). Hal 101. 
2) Suami melampaui batas yang disyari'atkan dalam menyakiti isteri baik fisik maupun psikis yang mengakibatkan isteri sengsara (dinilai secara kebiasaan lingkungan mereka).

3) Suami mengalami cacat badan yang berupa jab atau terpotongnya dzakar, Aniin atau impoten, gila, sopak dan kusta.

\section{Gugat Cerai Menurut Kompilasi Hukum Islam}

\section{a. Pengertian Gugat Cerai}

Putusnya perkawinan yang disebabkan karena perceraian dapat terjadi karena talak atau berdasarkan gugatan perceraian. (pasal 114, KHI). Dengan kata lain talak adalah perceraian karena suami yang mengajukan permohonan cerai kepada Pengadilan. Sedangkan gugat cerai yaitu gugatan perceraian yang diajukan oleh isteri atau kuasanya kepada Pengadilan yang daerah meliputi tempat kediaman penggugat. (pasal 73 (1), KHI)

Perceraian dengan talak biasa disebut cerai talak hanya berlaku bagi mereka yang melangsungkan perkawinan menurut agama Islam. Sedangkan bagi perceraian dengan gugatan biasa disebut cerai gugat berlaku bagi mereka yang melangsungkan perkawinan menurut agama Islam dan bukan agama Islam. Namun dalam pembahasan kali ini lebih difokuskan dari keluarga yang beragama Islam dan gugatan yang diajukan oleh pihak isteri atau kuasanya.

\section{b. Alasan-Alasan Gugat Cerai}

Pada dasarnya sebab-sebab gugat cerai harus sesuai dengan alasan perceraian, hal ini dijelaskan dalam kompilasi hukum Islam (KHI) pasal 116 :

Percerain dapat terjadi karna alasan atau alasan-alasan :

1. Salah satu pihak berbuat zina atau menjadi pemabuk, pemadat, penjudi dan lain sebagainya yang sukar disembuhkan.

2. Salah satu pihak meniggalkan pihak yang lain selama 2 (dua) tahun berturut-turut tanpa izin pihak lain dan tanpa alasan yang sah atau karena hal yang lain diluar kemampuanya. 
3. Salah satu pihak mendapat hukuman penjara 5 ( lima ) tahun atau hukuman yang lebih berat setelah perkawinan berlangsung.

4. Salah satu pihak melakukan kekejaman atau penganiayaan berat yang mambahayakan pihak yang lain.

5. Salah satu pihak mendapat cacat badan atau penyakit dengan akibat tidak dapat menjalankan kewajiban sebagai suami atau isteri.

6. Antara suami dan isteri terus menerus terjadi perselisihan dan pertengkaran dan tidak ada harapan akan hidup rukun lagi dalam rumah tangga.

7. Suami melanggar taklik talak.

8. Peralihan agama atau murtad yang menyebabkan terjadinya ketidakrukunan dalam rumah tangga.

Alasan yang bisa menjadikan perceraian juga tertuang dalam pasal 19 Peraturan Pemerintah No. 9 Tahun 1975 yang bunyi redaksinya sama (mulai awal isi pasal sampai huruf f) dengan pasal 116 KHI. Bedanya dengan pasal 19 Peraturan Pemerintah No. 9 Tahun 1975, pada redaksi pasal $116 \mathrm{KHI}$ ada tambahan dua huruf, yakni ; huruf $\mathrm{g}$ dan $\mathrm{h}$ yang bunyinya sebagaimana di atas.

Ada beberapa hal yang perlu diperhatikan mengenai alasan gugat cerai :

1. Karena salah satu pihak meninggalkan pihak lain selama 2 (dua) tahun berturut-turut tanpa izin pihak lain dan tanpa alasan yang sah atau karena hal lain diluar kemampuannya, maka gugatan perceraian dapat diajukan setelah lampau 2 (dua) tahun terhitung sejak tergugat meninggalkan rumah.

2. Karena antara suami dan isteri terus menerus terjadi perselisihan dan pertengkaran dan tidak ada harapan akan hidup rukun lagi dalam berumah tangga, maka gugatan perceraian dapat diterima apabila telah cukup jelas bagi pengadilan agama akan sebab-sebab perselisihan dan pertengkaran itu dan setelah mendengar pihak keluarga serta orangorang yang dekat dengan suami isteri tersebut. 
3. Karena suami isteri mendapat hukuman penjara 5 tahun ataun hukuman yang lebih berat, maka pengugat cukup menyampaikan salinan putusan pengadilan yang menyatakan bahwa putusan itu telah mempunyai kekuatan hukum tetap.

\section{Pendapat Hakim Pengadilan Agama Malang Tentang Impotensi Sebagai Salah Satu Alasan Gugat Cerai}

Dalam pemeriksaan perkara gugat cerai (bisa juga disebut cerai gugat) yang dilakukan oleh isteri, yang menjadi alasan perceraian karena suami (tergugat) telah menderita sakit impoten yang tidak melaksanakan kewajibannya sebagai suami sebagaimana ditentukan dalam pasal 19 (e) PP. No. 9 Tahun 1975 jo pasal 116 (e) KHI, maka cara pemeriksaannya disamping tunduk pada ketentuan hukum acara perdata pada umumnya, juga tunduk pada ketentuan yang diatur secara khusus dalam pasal 75 UU No. 7 Tahun 1989 yaitu : Apabila gugatan perceraian didasarkan atas alasan bahwa tergugat mendapat cacat badan atau penyakit dengan akibat tidak dapat menjalankan kewajiban sebagai suami, maka hakim dapat memerintahkan tergugat untuk memeriksakan diri kepada dokter.

Perlu dipahami terlebih dahulu bahwa isi Pasal 19 (e) PP. No. 9 Tahun 1975 dan Pasal 116 (e) Kompilasi Hukum Islam yang bunyinya sama. Yaitu : "Salah satu pihak mendapat cacat badan atau penyakit dengan akibat tidak dapat menjalankan kewajibannya sebagai suami atau isteri”.

Menurut Bapak Muzakki hakim Pengadilan Agama Malang, beliau menanggapi, bahwa Impotensi dapat dijadikan sebagai salah satu alasan gugat cerai dikarenakan tergugat tidak menjalankan kewajibannya sebagai suami disebabkan sakit impotensi. Apalagi jika dikuatkan dengan keterangan saksisaksi maka gugatan penggugat telah terbukti memenuhi Pasal 19 (e) PP No. 9 Tahun 1975 jo Pasal 116 (e) Kompilasi hukum Islam.

Sedangkan menurut Bapak Sukandar yang juga sebagai hakim Pengadilan Agama Malang, mengatakan hal yang sama dengan Bapak Muzakki dengan tambahan gugatan cerai tersebut tetap bisa dikabulkan meskipun suami tidak setuju untuk cerai. Hal ini karena isteri berhak untuk 
melakukan gugat cerai. Putusan tersebut bukan ditinjau dari setuju atau tidak setujunya suami (tergugat), melainkan terbukti atau tidak terbuktinya suami yang mengalami impotensi.

Secara spesifik impotensi adalah ketidak berdayaan pria melakukan hubungan seks melalui alat kelaminnya. Dalam pada ini pendapat Hakim Pengadilan Agama Kota Malang, yakni Bapak Edy Afan menegaskan bahwa impotensi dapat dijadikan sebagai alasan gugat cerai.

Pendapat Bapak Edy Afan tersebut dijabarkan dengan paparan beliau bahwa jika Pasal 19 (e) PP No. 9 Tahun 1975 dan Pasal 116 (e) KHI dikaitkan dengan impotensi, maka impotensi dapat dijadikan alasan gugat cerai dikarenakan dua unsur, yakni ; (1) cacat badan, dan (2) tidak dapat melaksanakan kewajiban sebagai suami.

Jadi para Hakim berpendapat bahwa impotensi dapat dijadikan sebagai salah satu alasan gugat cerai. Namun antara hakim yang satu dengan hakim yang lainnya berbeda dalam memberikan tanggapan.

\section{Bagan Tentang Pendapat Hakim Pengadilan Agama Malang}

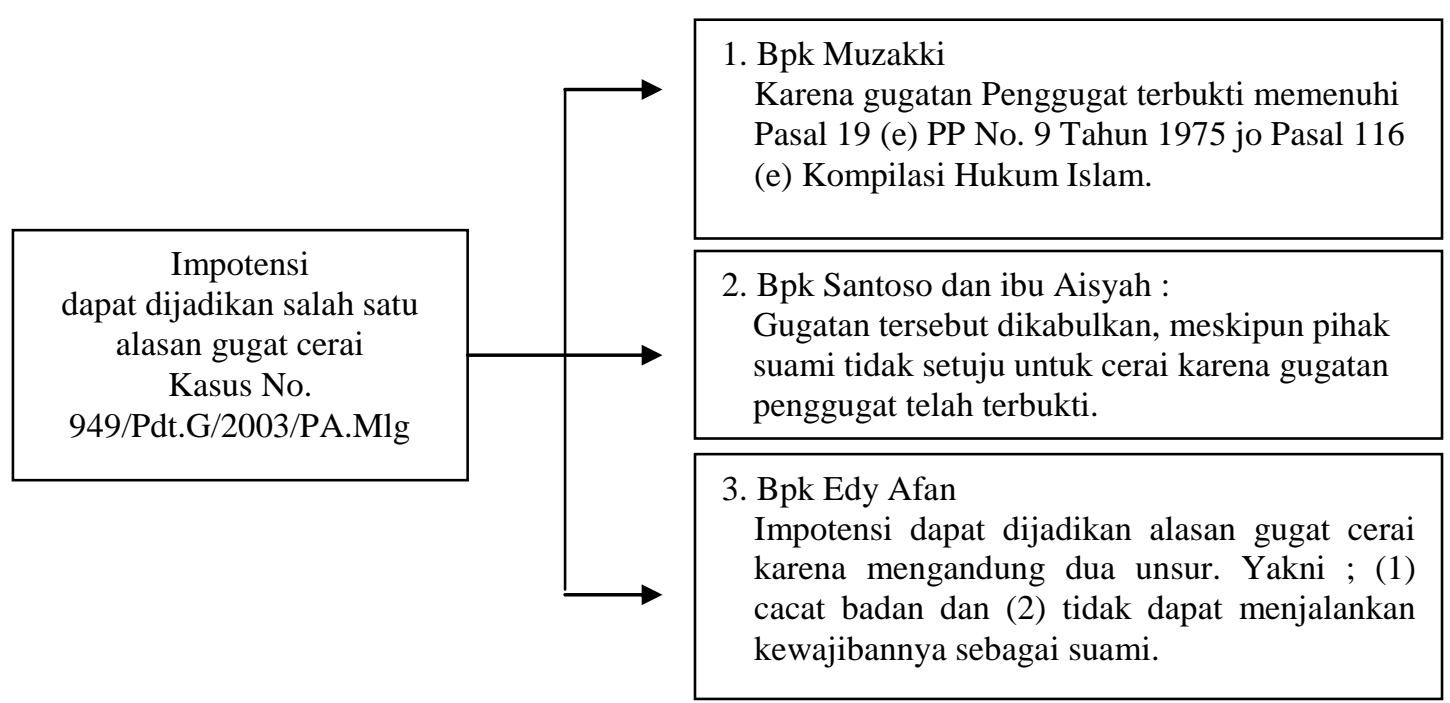




\section{E. Upaya Hakim Pengadilan Agama Malang dalam Menyelesaikan Gugat Cerai dengan Alasan Impotensi}

Ketentuan Pasal 75 UU No. 7 Tahun 1989 yang berbunyi :

"Apabila gugatan perceraian didasarkan atas alasan bahwa tergugat mendapat cacat badan atau penyakit dengan akibat tidak dapat menjalankan kewajiban sebagai suami, maka hakim dapat memerintahkan tergugat untuk memeriksakan diri kepada dokter".

Maka. jika Pasal 75 di atas dikaitkan dengan alasan yang disebut pada Pasal 19 (e) PP. No. 9 Tahun 1975 dan Pasal 116 (e) Kompilasi Hukum Islam yang bunyinya sama. Yaitu: "Salah satu pihak mendapat cacat badan atau penyakit dengan akibat tidak dapat menjalankan kewajibannya sebagai suami atau isteri".

Untuk menentukan dapat atau tidaknya suami melaksanakan kewajiban sebagaimana mestinya digantungkan pada dua faktor. Pertama faktor "keadaan fisik" (jasmani dan mental) bukan pada faktor kepribadian atau prilaku, jika jasmaninya cacat atau mentalnya sakit maka lahirlah akibat yang langsung menjadi faktor kedua yaitu "tidak dapat menjalankan kewajiban", yakni sifat ketidakmungkinan melaksanakan kewajiban bukan karena lalai atau menolak dengan sengaja. Suami benar-benar mau melaksanakan kewajiban, namun tidak dapat dilakukannya atau ia dalam keadaan impossibilitas disebabkan cacat atau sakit.

Tujuan hakim dapat memerintahkan tergugat untuk memeriksakan diri kepada dokter (upaya penyelesaian gugat cerai) agar mendapat gambaran fakta yang jelas tentang cacat atau penyakit impotensi yang diderita tergugat bersifat permanen atau temporer.

Jika menurut keterangan dokter sifat impotensi permanen, cukup alasan bagi hakim untuk mengabulkan gugatan isteri. Kalau impotensi bersifat temporer, dan sifat temporernya hanya untuk jangka waktu yang tidak lama, kurang tepat untuk mengabulkan gugatan. Ketidakmungkinan melaksanakan kewajiban yang dituntut pasal 116 (e) KHI adalah bisa menjadi dasar 
perceraian.. Cara penerapan yang demikian dapat disebut mengandung nilai edukatif dan preventif dalam kehidupan masyarakat.

Menurut hemat penulis, tekanan penerapan ketentuan Pasal 116 (e) KHI bukan pada impotensi, namun pada akibat yang ditimbulkan impotensi yakni tidak dapat menjalankan kewajiban. Dalam proses sidang perkara cerai gugat tersebut penggugat harus dapat membuktikan fakta-fakta tentang tidak dapatnya tergugat melaksanakan kewajiban. Bukan fakta-fakta impotensi yang harus dibuktikan.

Kalau impotensi sudah bersifat permanen (parah), sehingga telah menghancurkan sendi-sendi kesejahteraan dan kehidupan rumah tangga, dapat dibenarkan terjadinya perceraian, karena sesuai dengan ajaran Islam. Salah satu tujuan utama perkawinan itu sendiri adalah untuk membina dan mewujudkan kebahagiaan dan kesejahteraan lahir bati.

\section{Bagan Tentang Upaya Hakim}

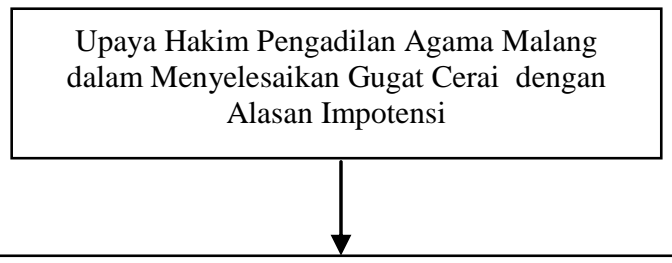

Drs H. A. Muzakki MH. : Cara penyeselaian kasus ini harus sesuai dengan ketentuan hukum acara perdata serta ketentuan khusus yang diatur dalam UU No. 7 Tahun 1989, tata tertib pemeriksaan juga harus berpedoman kepada azas-azas umum baik yang diatur dalam UU No. 4 Tahun 2004 maupun azas-azas dalam UU No. 7 Tahun 1989 dan KHI.

Anggota masyarakat terdidik dan dihalangi untuk cepat-cepat minta cerai. Impotensi yang bersifat permanen yang bisa dijadikan dalil gugatan dan terbukti.

Drs. M. Edy Afan : Upaya penyelesaian gugat cerai kasus ini sebagai berikut :

1. Hakim tidak secara langsung percaya dengan dalil gugatan

2. Mencocokkan dalil gugatan dengan alat bukti yang ada

3. Penerapan normatif undang-undang 


\section{DAFTAR PUSTAKA}

Alhamdani, A, S, 2002. Risalah Nikah, Jakarta : Pustaka Amani.

Al-Qur'an dan Terjemahnya, Jakarta, Departemen Agama RI, 2000.

Basyir, Azhar, Ahmad, 2004. Hukum Perkawinan Islam, Yogyakarta : UII Press

Bisri, Cik Hasan (penyunting), 1999. Kompilasi Hukum Islam dan Peradilan Agama, Jakarta : Logos Wacana Ilmu.

Mughniyah, Jawad, Muhammad, 2001. Fiqih Lima Mazhab, Jakarta : PT. Lentera Basritama.

Ragg, Marg, 1999. Mengatasi Impotensi, Jakarta : Arcan

Rusyd, Ibnu, Terj. Abdurrahman dan Abdullah, Haris, 1990. Bidayatul Mujtahid, Semarang : CV. Asyifa.

Sabiq, Sayyid. 1993. Fikih Sunnah 8, Bandung : PT. Almaarif.

Wijayakusuma, Hembing, 2000. Mengatasi Impotensi Secara Efektif dan Alamiah, Jakarta : PT Elex Media Komputindo. 